Jurnal Mandala Pharmacon Indonesia, Vol 6.No.2 Desember 2020

Avaiable online at www.jurnal-pharmaconmw.com/jmpi

p-ISSN : 2442-6032

$e$-ISSN : 2598-9979

\title{
Uji Efek Antiinflamasi Infusa Daun Bayam Merah (Amaranthus tricolor L.) Terhadap Tikus Putih (Rattus norvegicus) Yang Diinduksi Karagenan
}

\author{
Muhammad Isrul, Citra Dewi, Vivin Wahdini \\ Program Studi Farmasi, STIKES Mandala Waluya Kendari
}

\begin{abstract}
ABSTRAK
Daun bayam merah (Amaranthus tricolor L.) merupakan tumbuhan yang biasa ditanam untuk dikonsumsi daunnya karena memiliki banyak manfaat dan kandungannya bagi kesehatan tubuh dan daun bayam merah (Amarantus tricolor L.) mengandung komponen antioksidan. Penelitian ini bertujuan untuk mengetahui kandungan metabolit sekunder yang terkandung dalam infusa daun bayam merah (Amarantus tricolor L.) dan untuk mengetahui konsentrasi infusa daun bayam merah (Amarantus tricolor L.) yang dapat menghasilkan efek antiinflamasi. Penelitian ini menggunakan metode induksi karagenan sebagai

bayam merah (Amaranthus tricolor L.) memiliki metabolit sekunder yaitu, alkaloid, flavonoid, saponin, quinon, tanin, dan steroid. Infusa daun bayam merah (Amaranthus tricolor L.) efektif sebagai antiiflamasi pada konsentrasi 10\% dengan nilai $\mathrm{P}$ signifikan yaitu $0,778>0,05$ dan konsentrasi $25 \%$ dengan nilai $\mathrm{P}$ signifikan yaitu $0,725>0,05$. Konsentrasi tersebut tidak berbeda signifikan dengan kontrol positif Natrium diklofenak. Dari hasil penelitian ini dapat ditarik kesimpulan infusa daun bayam merah (Amaranthus tricolor L.) dapat menghambat pembentukan udema.
\end{abstract} zat iritannya. Infusa daun bayam merah (Amaranthus tricolor L.) dibuat dalam berbagai variasi konsentrasi $10 \%$, $15 \%$ dan $25 \%$ yang diberikan secara oral pada tikus putih. Natrium diklofenak digunakan sebagai kontrol positif, $\mathrm{Na}$ CMC digunakan sebagai kontrol negatif. Pengukuran dilakukan setiap 30 menit selama 180 menit setelah induksi karagen 1\% 0,2 ml. Analisis data dilakukan dengan menggunakan One-Way ANOVA dan dilanjutkan dengan uji LSD. Daun
Keywords: Infusa, daun bayam merah (Amaranthus tricolor L.), antiinflamasi

Penulis Korespondensi :

Muhammad Isrul

Program Studi Farmasi, STIKES Mandala Waluya Kendari

E-mail : isrulfar@gmail.com

\section{PENDAHULUAN}

Inflamasi merupakan respon perlindungan normal terhadap cedera jaringan yang disebabkan trauma fisik, bahan kimia berbahaya atau agen mikrobiologi. Inflamasi adalah usaha tubuh untuk menginaktif atau menghancurkan organisme penginvasi, menghilangkan iritan dan persiapan tahapan untuk perbaikan jaringan, bila penyembuhan telah sempurna proses inflamasi biasanya mereda (Champe dan Richaech, 2013).
Inflamasi juga terlibat dalam patogenesis penyakit aterosklerosis, obesitas dan diabetes, beberapa jenis kanker, stroke, asma bronkial, radang sendi dan demensia. Proses ini menyebabkan tanda-tanda utama inflamasi akut yakni rubor (kemerahan), kalor (panas), tumor (pembengkakan), dan dolor (nyeri) (Porth, 2015).

Untuk mengatasi inflamasi dapat dilakukan dengan pemberian obat-obatan antiinflamasi golongan steroid maupun 
golongan Antiinflamasi Non Steroid (AINS). Keduanya memiliki efek samping yang merugikan, golongan steroid dapat menyebabkan penurunan imunitas terhadap infeksi, osteoporosis, atropi otot dan jaringan lemak, meningkatkan tekanan intraoekular. Sedangkan golongan AINS menyebabkan tukak lambung hingga pendarahan, gangguan ginjal dan anemia (Atiek et al., 2011).

Obat antiinflamasi sintetik memiliki beberapa efek samping seperti kerusakan lambung, hati, dan juga. Banyaknya efek samping yang merugikan dari penggunaan obat-obat sintetik, sehingga perlu dicari pengobatan alternatif untuk mengendalikan rasa nyeri dan peradangan dengan efek samping yang relatif lebih kecil maka digunakan obat bahan alam sebagai pilihan (Anwar et al., 2013).

Salah satu tumbuhan yang berkhasiat sebagai obat adalah daun bayam merah (Amarantus tricolor L.) dan sering dikonsumsi karena banyak manfaat dan kandungannya bagi kesehatan tubuh (Saparinto, 2014). Daun bayam merah (Amarantus tricolor L.) mengandung komponen antioksidan antara lain betalain (pigmen warna tumbuhan), karotenoid, vitamin C, flavonoid dan polifenol (Wiyasihati et al. 2016). Salah satu kandungan kimia dari daun bayam merah (Amaranthus tricolor L.) dapat berkhasiat sebagai antiinflamasi yaitu flavonoid. Hal ini didukung oleh penelitian Nijveltd et al. (2014) menunjukan mekanisme flavonoid sebagai antiinflamasi melalui jalur penghambatan siklooksigenase atau lipooksigenase, akumulasi leukosit di daerah yang cedera, degradasi neutrofil dan penghambatan pelepasan histamin.

Berdasarkan penelitian Amornrit dan Santiyanont, (2015) daun bayam merah (Amaranthus tricolor L.) juga telah terbukti mengandung antioksidan sebagai neuroprotektif dalam menurunkan stres oksidatif dan inflamasi yang disebabkan oleh Advanced glycation end-products (AGE) sehingga resiko terjadinya neurodegeneratif menurun. Penelitian lain yang dilakukan oleh Al-Dosari (2010) menunjukan bahwa adanya sifat hepatoprotektif berupa antioksidan pada ekstrak etanol daun bayam merah (Amaranthus tricolor L.) terhadap tikus yang diinduksi $\mathrm{CCI}_{4}$, hal ini ditandai dengan berkurangnya nekrosis dan inflamasi, penurunan enzim transaminase, bilirubin dan kadar lipid serum pada tikus.

Beberpa penelitian telah membuktikan aktivitas daun bayam merah sebagai antioksidan dan hepatoprotektif, Pada penelitian akan menelusuri aktivitas baru yaitu sebagai antiinflamasi. Pada penelitian ini menggunakan metode induksi karagenan. Metode ini dipilih karena sederhana, mudah dan cocok untuk pengujian aktivitas antiinflamasi suatu senyawa dalam jumlah yang kecil. Pada metode ini tikus disuntikkan karagenan secara subplantar untuk menginduksi terbentuknya udema dan aktivitas senyawa uji ditinjau dari kemampuannya dalam menghambat udema yang diinduksi pada tikus putih (Rattus norvegicus) (Agbaje dan Fageyinbo, 2012).

Berdasarkan uraian diatas, mengingat potensi yang begitu besar dari daun bayam merah (Amaranthus tricolor L.) namun masih kurangnya informasi ilmiah penggunaan daun bayam merah sebagai antiinflamasi. Untuk itu penelitiann ini dilakukan agar mengetahui efek antiinflamasi dari infusa daun bayam merah (Amarantus tricolor L.) pada tikus putih (Rattus norvegicus L.) dengan metode induksi karagenan 
METODE PENELITIAN

\section{Pengambilan dan Penyiapan Sampel}

\section{a. Pengambilan Sampel}

Sampel daun bayam merah (Amaranthus tricolor L.) diperoleh dari Desa Lamomea, Kecamatan Konda, Kabupaten Konawe Selatan.

\section{b. Determinasi Sampel}

Dilakukan determinasi tanaman dengan tujuan untuk menetapkan kebenaran mengenai Amaranthus tricolor L. diidentifikasi atau dideterminasi dilakukan di Laboratorium Pengembangan Jurusan Biologi Universitas Halu Oleo.

\section{c. Pengolahan Sampel}

Sampel yang digunakan selanjutnya disortasi dan dicuci dengan air mengalir agar menghilangkan kotoran-kotoran yang menempel pada sampel. Selanjutnya sampel dikeringkan dengan cara dianginanginkan dan terlindung dari cahaya matahari langsung selama 2-3 hari. Ukuran simplisia diperkecil lalu disimpan dalam wadah tertutup rapat.

\section{Pembuatan Ekstrak Sampel Daun Bayam Merah (Amaranthus tricolor L.) Metode Infusa}

Ekstrak daun bayam merah sebanyak 25 gram masukan dalam gelas kimia $250 \mathrm{ml}$ kemudian tambahkan $100 \mathrm{ml}$ aquades. Lalu dipanaskan diatas penangas air selama 15 menit terhitung mulai suhu mencapai $90^{\circ} \mathrm{C}$ sambil sekali-kali diaduk. Hasil rebusan disaring menggunakan kertas saring,jika volume kurang dari 100 ml maka ditambahkan air hangat melalui residu infusa hingga volumenya mencapai $100 \mathrm{ml}$.

\section{Skrining Fitokimia}

Skrining fitokimia dengan penambahan reagen dilakukan untuk memastikan kebenaran zat kimia yang terkandung didalam daun bayam merah (Amaranthus tricolor L.). Identifikasi senyawa meliputi alkaloid, flavonoid, saponin, sterol dan triterpenoid, tanin dan polifenol dengan menggunakan pereaksi masing-masing yaitu dragendorf, sitoborat, Liebermanburchard, dan $\mathrm{FeCl}_{3}$ (Isrul,2018; Isrul, 2019)

\section{Penyiapan Bahan Uji}

\section{a. Pembuatan Larutan Na CMC $1 \%$}

Ditimbang Na CMC sebanyak 1 gram, kemudian dimasukan dalam gelas kimia $100 \mathrm{ml}$ sedikit demi sedikit yang sudah berisi $50 \mathrm{ml}$ air suling diaduk menggunakan batang pengaduk sampai terbentuk larutan koloidal, lalu volumenya dicukupkan dengan air suling hingga $100 \mathrm{ml}$ dan larutan disimpan dalam wadah tertutup baik.

\section{b. Pembuatan Suspensi Natrium diklofenak}

Disiapkan natrium diklofenak sebanyak 10 tablet lalu ditimbang, kemudian dihitung bobot rata-rata lalu digerus sampai halus. Serbuk natrium diklofenak ditimbang kembali kemudian disuspensikan dalam larutan Na CMC 1\% sedikit demi sedikit sambil diaduk hingga homogen lalu dimasukkan ke dalam gelas kimia $50 \mathrm{ml}$ kemudian volumenya dicukupkan sampai $50 \mathrm{ml}$.

\section{c. Pembuatan Suspensi Karagenan $1 \%$}

1 gram serbuk karagenan, dilarutkan dengan $\mathrm{NaCl}$ 0,9\% sebanyak $30 \mathrm{ml}$ dalam gelas kimia.

\section{Pemilihan dan Penyiapan Hewan Uji}

Hewan uji yang digunakan adalah tikus putih (Rattus norvegicus), yang berusia 8 minggu dengan berat badan 100-250 gram, kondisi hewan yang digunakan sehat.

Dalam penelitian ini, tikus dibagi dalam dua kelompok kontrol perlakuan dan tiga kelompok perlakuan, dan jumlah sampel perkelompok 5 ekor sehingga didapat jumlah sampel 25 ekor tikus. 
Tikus putih (Rattus norvegicus) diadaptasi dalam kandang pada suhu ruangan kurang lebih selama 1 minggu untuk proses aklimatisasi. Selama proses tersebut tikus diberi makan pakan tikus dan minum. Setelah 1 minggu tikus dipuasakan selama 18 jam sebelum perlakuan, namun tetap diberikan air minum. Setiap tikus diberi tanda pada ekor untuk membedakan tikus satu dengan yang lain dan diberi tanda dengan spidol pada sendi belakang kiri tikus agar saat memasukan kaki tikus ke dalam plestismometer selalu sama.

\section{Perlakuan Terhadap Hewan Uji}

a. Tikus ditimbang berat badannya terlebih dahulu kemudian dikelompokan secara acak menjadi 5 kelompok. Kemudian diukur volume kaki tikus sebelum perlakuan sebagai volume awal.

b. Kemudian sediaan diberikan peroral dengan volume sebagai berikut:

a) Kelompok I : 5 ekor tikus diberi suspensi $\mathrm{Na} \mathrm{CMC}$ 0,05 $\mathrm{ml}$ peroral sebagai kontrol negatif.

b) Kelompok II : 5 ekor tikus diberi larutan natrium diklofenak 0,05 $\mathrm{ml}$ secara peroral sebagai kontrol positif.

c) Kelompok III : 5 ekor tikus diberi infusa daun bayam merah dengan konsentrasi $10 \%$.

d) Kelompok IV : 5 ekor tikus diberi infusa daun bayam merah dengan konsentrasi $15 \%$.

e) Kelompok V : 5 ekor tikus diberi infusa daun bayam merah dengan konsentrasi $25 \%$.

c. 1 jam kemudian setelah diberikan perlakuan, masing-masing telapak kaki tikus diinduksi karagenan $1 \%$ sebanyak $0,2 \mathrm{ml}$ secara subplantar sebelumnya kaki tikus dibersihkan dengan alkohol 70\%.

d. Setelah 1 jam disuntikan karagenan, volume kaki tikus diukur dengan menggunakan alat plestismometer untuk setiap selang waktu 30 menit selama 3 jam pengamatan.

e. Dicatat setiap hasil pengukuran dan dihitung persentase penghambatan udem

f. Data yang diperoleh dianalisis secara statistik terhadap volume telapak kaki tikus (Ebta et al, 2016).

\section{Pengolahan dan Analisis Data}

Analisis data yang digunakan dalam persentase penghambatan radang yaitu dengan menggunakan uji Kolmogorov Smirnovz untuk melihat distribusi data apakah normal atau tidak dan uji Levene untuk melihat homogenitas data. Apabila data terdistribusi normal maka dilanjutkan dengan uji Analisis Varian (ANOVA) dengan taraf kepercayaan 95\% sehingga dapat diketahui apakah perbedaan yang diperoleh bermakna atau tidak (Santoso, 2008). Apabila terdapat perbedaan bermakna, maka dilanjutkan dengan uji beda nyata terkecil LSD (Least Significant Difference).

\section{HASIL DAN PEMBAHASAN}

Hasil Skirining Fitokimia ditunjukkan pada tabel 1. Hasil skrining menunjukkan Ekstrak Bayam Merah positif mengandung alkaloid, flavonoid, saponin, kuinon, tanin dan steroid.

Tabel 1. Hasil Skrining Fitokimia Ekstrak Bayam Merah

\begin{tabular}{cc}
\hline Jenis Senyawa & Hasil \\
\hline Alkaloid & Positif (+) \\
\hline Flavonoid & Positif (+) \\
\hline Saponin & Positif (+) \\
\hline Quinon & Positif (+) \\
\hline Tanin & Positif (+) \\
\hline Triterpenoid & Negatif (-) \\
\hline Steroid & Positif (+) \\
\hline
\end{tabular}

Hasil pengujian aktivitas antiinflamasi ekstrak Bayam Merah ditunjukkan pada tabel 2 dan Gambar 1. 
Tabel 2. Rerata \% inhibisi udem

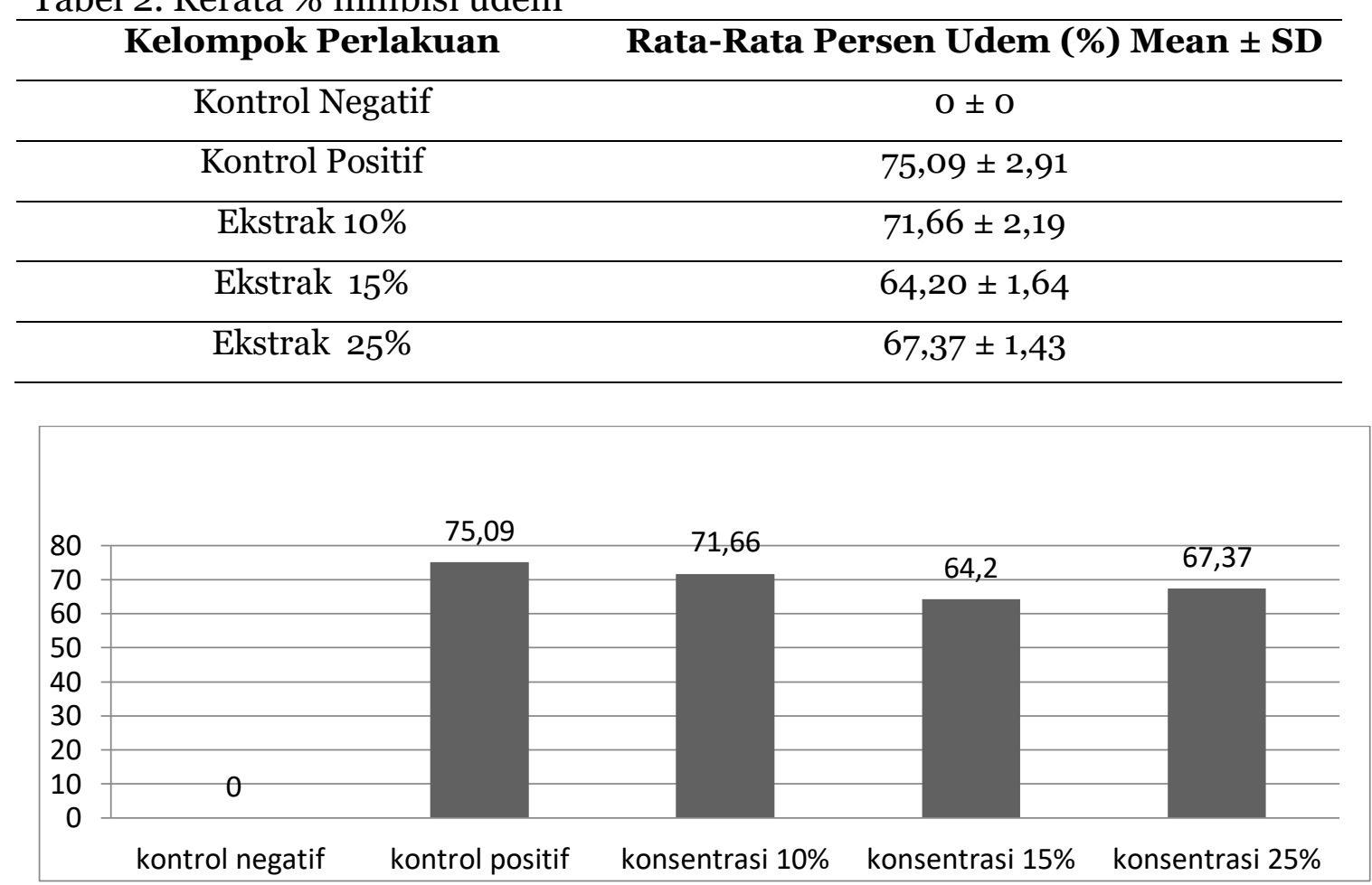

Gambar 1. Hasil \% inhibisi udem pada kaki tikus.

Pada penelitian dilakukan pengujian efek antiinflamasi menggunakan sampel daun bayam merah (Amaranthus tricolor L.). Tujuan dari penelitian ini adalah untuk mengetahui kandungan metabolit sekunder yang terkandung dalam infusa daun bayam merah (Amarantus tricolor L.) dan untuk mengetahui konsentrasi infusa daun bayam merah (Amarantus tricolor L.) yang dapat menghasilkan efek antiinflamasi.

Pada penelitian ini dilakukan identifikasi kandungan kimia tujuannya untuk mengetahui keberadaan golongan metabolit sekunder yang terdapat dalam infusa daun bayam merah (Amaranthus tricolor L.) secara kualitatif . Berdasarkan identifikasi yang telah dilakukan pada tabel 1 didapatkan hasil infusa daun bayam merah (Amaranthus tricolor L.) positif memiliki senyawa kimia berupa alkaloid, flavonoid, saponin, quinon, tanin dan steroid.

Pada penelitian ini dilakukan pengujian uji efek antiinflamasi infusa daun bayam merah (amaranthus tricolor 1.). penelitian ini menggunakan hewan uji tikus putih (Rattus norvegicus), yang berusia 8 minggu dengan berat badan 100-250 gram, kondisi hewan yang digunakan sehat. Alasan pemilihan tikus sebagai hewan uji karena keunggulannya, yang lebih besar dari mencit, mudah dipelihara dalam jumlah yang banyak, dan tikus putih dipilih karena tikus memiliki proses absorbsi sistem pencernaan dan sistem metabolisme terhadap obat uji yang relatif mirip dengan sistem pencernaan manusisa (Akbar, 2010). Pemilihan jenis kelamin jantan didasarkan pada pertimbangan tikus jantan memiliki kestabilan hormonal dibanding tikus betina, karena tikus betina mengalami siklus estrus masa kehamilan dan menyusui yang akan mempengaruhi kondisi psikologi hewan uji, tikus jantan tidak memiliki hormon estrogen waupun adanya jumlahnya sangat sedikit (Yasinta et al., 2017)

Sebelum dilakukan pemberian larutan uji semua tikus pada setiap 
kelompok dilakukan pengukuran volume awal kaki kiri menggunakan alat plestismometer. Prinsip dari plestismometer pengukuran berdasarkan hukum Archimedes, yang menyatakan bahwa apabila benda dimasukan ke dalam zat cair, maka akan menimbulkan gaya atau tekanan ke atas (Necas, 2013). Setelah itu dilakukan pemberian larutan uji secara oral selang waktu pemberian semua perlakuan adalah 60 menit sebelum diberikan induksi suspensi karagenan dengan tujuan selang waktu 60 menit telah dapat menimbulkan efek secara maksimal untuk menurunkan udem. Setelah 60 menit disuntikan induksi karagenan $1 \%$ sebanya $0,2 \mathrm{ml}$ secara suplantar pada kaki kiri tikus dengan selang waktu pengukuran udema 30 menit selama 3 jam. Penyuntikan karagenan melalui rute subplantar akan meningkatkan kadar COX-2 sehingga pembentukan udema berlangsung cepat dan sesuai dengan tujuan penyuntikan karagenan yang akan disuntikkan pada telapak kaki tikus.

Pemilihan karagenan sebagai peginduksi yaitu untuk menguji obat antiinflamasi karena tidak bersifat antigenik dan tidak menimbulkan efek sistemik (Nur et al., 2008). Penggunaan karagenan sebagai penginduksi radang karena tidak meninggalkan bekas, tidak menimbulkan kerusakan jaringan, dan memberikan respon yang lebih peka terhadap obat antiinflamasi dibanding dengan senyawa iritan lainnya (Endah, 2013). Pengamatan secara visual yang terjadi dalam proses inflamasi pada kaki tikus ditandai dengan adanya kemerahan (rubor) dan pembengkakan karena perubahan pada pembuluh darah yang menyebabkan peningkatan aliran darah dan edema (tumor). Perubahan ini dapat teraktivasi dalam beberapa detik dan bertahan dalam hitungan menit hingga jam. Mediator inflamasi akut dalam jaringan yang ternflamasi menyebabkan kontraksi endotel pembuluh darah yang disertai hilangnya taut antarsel. Hal ini menyebabkan akumulasi cairan dijaringan interstitial yang menimbulkan pembengkakan jaringan atau tumor (King TC, 2007).

Berdasarkan hasil pengujian antiinflamasi dengan mengamati adanya udema pada hewan coba tikus menunjukkan persentase inhibisi dari Kontrol negatif, kontrol positif, infusa bayam merah konsentrasi 10\%,15\%, dan $25 \%$ masing-masing adalah $0,75,05 \%$, 71,66\%, 64,20\%, dan 67,37 \%. Hasil analisis statistik Anova dan uji lanjutan LSD menunjukkan semua kelompok perlakuan memperlihatkan perbedaan signifikan dengan control negatif ini menunjukkan semua kelompok perlakukan memperlihatkan efek antiinflamasi. Infusa daun bayam merah konsentrasi 10\% dibanding kontrol positif Natrium Diklofenak memperlihatkan tidak ada perbedaan yang menujukkan konsentrasi 10\% memiliki efek yang sama dengan kontrol positif dalam penghambatan pembentukan udem

Pada hasil penelitian ini infusa daun bayam merah konsentrasi 10\% dan $25 \%$ dapat memberikan efek antiinflamasi dengan penghambatan pembentukan udem karena adanya senyawa flavanoid yang memiliki aktivitas antioksidan yang menghambat terbentuk mediatormediator kimia yang dapat menyebabkan radang. Hal ini sesuai dengan penelitian Al-Dosari (2010) menunjukan bahwa adanya antioksidan pada ekstrak etanol daun bayam merah (Amaranthus tricolor L.) terhadap tikus yang diinduksi $\mathrm{CCI}_{4}$, ditandai dengan berkurangnya nekrosis dan inflamasi pada tikus. 


\section{KESIMPULAN}

Kesimpulan dari penelitian ini yaitu :

1. Infusa Bayam Merah (Amaranthus tricolor L.) mengandung metabolit sekunder alkaloid, flavonoid, saponin, quinon, tanin, dan steroid.

2. Infusa Bayam Bayam Merah (Amaranthus tricolor L.) memiliki aktivitas antiinflamasi pada konsentrasi $10 \%, 15 \%$, dan $25 \%$, konsentrasi $10 \% \quad$ merupakan konsentrasi efektif yang menunjukkan aktivitas yang sama dengan control positif natrirum diklofenak.

\section{UCAPAN TERIMA KASIH}

Peneliti mengucapkan terima kasih kepada Prodi Farmasi dan STIKES Mandala Waluya yang mendukung kegiatan penelitian ini.

\section{DAFTAR PUSTAKA}

Ebta Narasukma Anggraeny, Anatasia Setyopuspito P. 2016. Studi Uji Daya Antipiretik Ekstrak Etanol Daun Lengkeng (Dimocarpus longan L) Pada Tikus Putih Jantan (Rattus norvegicus) Galur Wistar. Jurnal Ilmia Farmasi.

Agbaje E.O., F. M. S. 2012. Evaluating AntiInflammatory activity of aquous root extract of Strophantus hispidus DC. (Apocynaceae). International Journal of Applied Research in Natural Products, 4, pp. 7-14.

Akbar, Budhi. 2010. Tumbuhan Dengan Kandungan Senyawa Aktif Yang Berpotensi Sebagai Bahan Antifertilitas. Ed. 1, Jakarta: Adabia Press.

Al-Dosari, M. S. 2010. The effectiveness of ethanolic extract of Amaranthus tricolor L: A natural hepatoprotective agent. The American Journal of Chinese Medicine., pp. 1052-1062.

Amornrit, W. and Santiyanont, R. 2015. Effect of amaranthus on advanced glycation end-products induced cytotoxicity and proinflammatory cytokine gene expression in $\mathrm{SH}_{-} \mathrm{SY}_{5} \mathrm{Y}$ cells. Molecules.

Anwar K, Santoso BH, C. N. 2013. Penghambatan Radang Infusa Daun Dadap Ayam (Erythrina veriegale L.) pada mencit jantan yang dïnduksi karagenin.Prosiding Semirata FMIPA Universitas Lampung., pp. 45-52.

Champe PC, R. A. 2008. Farmakologi Ulasan Bergambar. Jakarta : EGC.

Dalimartha 2004. Deteksi Dini Kanker dan Simplisia Anti Kanker., Jakarta: Penebar Swadaya.

Departemen Kesehatan RI 2000. Sediaan Galenik., Jakarta: Departemen kesehatan RI.

Endah P. 2013. Uji Efek Antiinflamasi Ekstrak Etanol Lumut Hati Mastigophora diclados (Bird, ex Web.) Nees secara In Vivo. Tesis, Fakultas Kedokteran Ilmu Kesehatan, Jakarta.

Isrul, M., Idrus, M., Mashar, H.M. and Muthmainnah, A., 2018. Antimycobacterial activity of Gynura procumbens leaves extract against Mycobacterium tuberculosis. International Journal of Green Pharmacy, 12(3), pp.163-167.

Isrul, M., Juliansyah, R., Saleh, A., Yuliastri, W.O., Pusmarani, J. and Maulidina, W.O.W., 2019. Phytochemical Analysis, Standardization and Cytotoxic Activity of Curcuma aureginosa Extract in Human Breast Cancer (MCF-7) Cell Line. Research Journal of Pharmacy and Technology, 12(4), pp.1967-1973.

King TC. 2007. Elsevier's Integrated Pathology. Philadelphia: Mosby Elsevier.

Necas, J., Bartosikova, L. (2013). Carrageenan: a review, Faculty of Medicine and Dentistry. Palacky University. Olomounc. Czech Republic: Veterinarni Medicina. 58 (4): 187-205.

Saparinto, C. 2013. Grown Your Own Vegetables - Panduan Praktis Menanam Sayuran Konsumsi Populer di Pekarangan. Yogyakarta: Lyli Publisher.

Wiyasihati, S. I., dan W. K. W. 2016. Potensi Bayam Merah (Amaranthus tricolor L) sebagai Antioksidan pada Toksisitas Timbal yang Dïnduksi pada Mencit. 48 , pp. 63-67.

Yasinta, Hatuti, Joni dan Sri. 2017. Efektivitas Anthiperurisemia Ektrak Etanol Daun Seledri (EDDS) Pada Tikus Putih Induksi Kalium Oksonat. J Trop Pharm. Chem. Vol 4. No.1. 